\title{
INCLUSIVISM AND EXCLUSIVISM AS WELL AS THEIR EFFECT ON ISLAMIC EDUCATION BASED MULTICULTURAL
}

\section{Dhikrul Hakim}

Email:dhikrulhakim@fai.unipdu.ac.id

Faculty of Islamic Religion

Universitas Pesantren Tinggi Darul 'Ulum Jombang

\begin{abstract}
The majority of Indonesia's population embraces Islam, there are some of other religions and beliefs that are also recognized and adhered to by residents in this country, Christians, Catholics, Hindus, Buddhists and Confucians. Indonesian society is a society with a very complex level of diversity, the diversity is known as a multicultural society. This implies that without media in the form of education, plural theology will be difficult to develop in Indonesia. With education, we can have strong basics in understanding differences because essentially education is a process of "an effort to humanize humans". This method of scientific work uses qualitative methods with a library research approach. The results of this scientific work are, Religious education based multicultural that is a process of awareness based on tolerance which is intended as a comprehensive effort to prevent conflicts between religions, prevent religious radicalism, while at the same time foster the realization of positive appreciative attitudes towards plurality, inclusivism in dimensions and any perspective does not promote exclusivism. Religion should be able to be a promoter for humanity to always uphold the peace and improve the welfare of all human beings on this earth. Unfortunately, in real life, religion is often been one of the causes of humanity's violence and destruction. Thus, the fulcrum of religious education based multicultural inclusivism actually lies in the understanding and the effort to live together in the context of religious and cultural differences.
\end{abstract}

Keywords: Inclusivism, Exclusivism, Religious, and Multicultural

\section{INTRODUCTION}

Indonesian people have so much diversity, not only a matter of customs or culture of art, language and race, but also including the problem of religion. Even though the majority of the Indonesian population embraces Islam, there are some of 
other religions and beliefs that are also recognized by these Indonesian people; Christians, Catholics, Hindus, Buddhists and Confucians. Indonesian society is a society with a very complex level of diversity, people with a variety of diversity are known as multicultural societies.

Religious diversity is a sunnatullah. As the diversity in language, ethnicity and culture; For that, the Al-Qur'an has given instructions to the people in addressing religious diversity in the form of two clear and decisive attitudes. Namely: an exclusive attitude (al-inghilaq) in matters that are related to aqidah and 'ubudiah; and inclusive attitude (al-infitah) in the interactive social sphere. In the applicative level, the Muslim doctrines that are sourced from Al-Qur'an and As-Sunnah have taught their community how to live side by side with societies that have different faith. The Medina Charter is one of the historical evidence of how Islam from the outset wanted the harmony among religious believers. In the context of Indonesians, the noble values of Al-Qur'an can be developed in order to maintain the various pillars that need to be agreed upon and actualized to build the harmony among religious believers. Among these pillars is to increase the right attitude of tolerance, respect each other with attitudes of maturity in religion, increase cooperation in matters that become a common goal in religion, without distrusting each other and strengthen the three pillars of statehood (Pancasila, UUD 45 and Bineka Tunggal Ika). ${ }^{1}$

The diversity of religions that are embraced by the Indonesian people is proof that the Indonesian people uphold Human Rights. Because the freedom of religion is the essence of human nature's right to be devoted to its creator, God Almighty according to his conscience. Every religion certainly has its own rules in worship. But this difference is not a reason for being division. As one brother in the same homeland, every Indonesian citizen is obliged to maintain the religious harmony in Indonesia so that this country can stay in full of harmony and attains its goal as a prosperous and socially country.

The challenge of Islamic education today is to change the paradigm of human thinking from exclusive attitudes to be inclusive. Hostility becomes brotherhood, because according to Ahmad Ludjito in "Filsafat Nilai dalam Islam" in the Chabib Thohaet.al, "Reformulasi Filsafat Pendidikan Islam", education is essentially a process of "an effort to humanize humans". This implies that without education in the form of structural theology, it will be difficult to develop in this earth. Education and science

${ }^{1}$ Moh Abdul Kholiq Hasan, Merajut Kerukunan Dalam Keragaman Agama Di Indonesia Perspektif Nilai Nilai Al-Quran) PROFETIKA, Jurnal Studi Islam,Vol.14,No.1,Juni 2013: p. 66-67. 
are something great because with our education, we can have strong basics in understanding differences. ${ }^{2}$

One of the reasons for education in Indonesia is the strong pattern of adaptation with local culture. In line with these adaptations, the doctrine of Islamic education that was developed in Indonesia at an early stage is full of exchange values. Or it has been able to display the face of Islam that is moderate and does not like violence. However, the adaptive and tolerant nature of this institution is being questioned nowadays. This is caused by the number of terrorist accidents and violence that occurred in Indonesia a few years ago, carried out by a number of people who graduated from Islamic boarding school. Later, Some of them generalized that Islamic boarding school is the breeding ground that created students who are intolerant of differences. These perceptions and views are deemed inappropriate because Islam in discerning the diversity is something that is inevitable and becomes the reality of human life. Many surahs of Al-Quran explain the reality of those sunnatullah. In addition, Al- Qur'an emphasizes the inevitability of human diversity in SARA, AlQur'an also asks for all its followers to do a good and fair work for every human being, although for other religion.

\section{ARTICLE WRITING METHOD}

In writing this scientific journal article, the writer uses a qualitative method using a literature approach. According to Kirk and Miller, explain that qualitative research is a particular tradition in social science that fundamentally depends on human observations in their own region and relates to these people in their language and terminology. While the literature approach is a study that uses data analysis based on written material, library materials in the form of published notes, books, magazines, newspapers, manuscripts, journals or articles. ${ }^{3}$

\section{The Understanding of Inclusive (Al-Infitah) and Exclusive (Al-Inghilaq)}

Every religion must have exclusive (al-inghilaq) and inclusive (al-infitah) sides which greatly influence one's religious attitude. This exclusive side (al-inghilaq) is reflected in problems, especially in faith and worship. Every religion has its own specialties that are not owned by other religions and should not be mixed. Because mixing these two things with other beliefs is believed not only to make the faith and worship rejected, but also can eliminate the existence of religion itself and ultimately will affect the harmony between religious believers and even make unhealthy social

\footnotetext{
${ }^{2}$ Ahmad Lutdjito, Filsafat Nilai dalam Islam dalam Chabib Thohaet.al, Reformulasi Filsafat Pendidikan Islam, (Yogyakarta: Pustaka Pelajar dan FT.IAIN Walisongo Semarang, 1996), p. 21.

${ }^{3}$ Lexy J Moleong, Metodologi Penelitian Kualitatif(Bandung: Remaja Rosda karya, 2006) p. 7
} 
conditions. While the Inclusive (al-infitah) side is reflected in social, community, national and state attitudes. ${ }^{4}$

a) Inclusive is an attitude of open minded and respect the differences, even the differences in the form of opinions, thoughts, ethnicity, cultural traditions and religious differences. ${ }^{5}$ Then, open minded attitude becomes the main prerequisite for interfaith dialogue, tradition or dialogue between civilizations with the aim that there is no absholut and extreme justification in opinion or religion, but this is not what the writer intended as an inclusive paradigm, but rather a goal to find universal truth in every difference or just not suspect each other. An inclusive attitude (al-infitah) will create an attitude to respect and appreciate the existence of other religious communities.

Because their own religion's doctrine demands to respect the existence of other religions that are recognized by its adherents as truth as well, then this is a manifestation of the inclusiveness attitude. This attitude is always followed by giving opportunities and freedom for religious adherents to perform their rituals and worship according to what they believe. In acknowledging the claims of others for the truth of their religion, whatever the form of recognition, an inclusive person never loses his character and identity as someone who obeys and defends the truth of his religion. He actually shows his religious identity as the exercise of the noble values of his own religion over the recognition of others of his own religion, and with the spirit of its diversity he can associate and communicate elegantly with adherents of other religions while still holding the universal truth principle of his religion. ${ }^{6}$

Islam is basically as a rahmatan lil'ala-min (the blessing of the entire universe) religion, although Islam itself has affirmed that the true religion is Islam (Ali Imran/3: 19 and 85):

Meaning: "Lo! religion with Allah (is) the Surrender (to His Will and Guidance). Those who (formerly) received the Scripture (Al Kitab ${ }^{7}$ ) differed only after knowledge came unto them, through transgression among themselves. Whoso disbelieveth the revelations of Allah (will find that) lo! Allah is swift at reckoning."

\footnotetext{
${ }^{4}$ See Moh Abdul Kholiq Hasan, Merajut Kerukunan ..., p. 70.

${ }^{5}$ M. Ainul Yaqin, Pendidikan Multikultural, Cross-Cultural Understanding Untuk Demokrasi dan Keadilan, (Yogyakarta: Pilar Media, 2005), p. 34.

' Iskandar Zukarnain, "Realitas Keagamaan di Indonesia dan Inklusifitas Islam", makalah seminar, di LorInSolo,18-20Juni2012.

${ }^{7}$ Means that the Holy Books that are sent down before Qur'an.
} 
Meaning: "And whoso seeketh as religion other than the Surrender (to Allah) it will not be accepted from him, and he will be a loser in the Hereafter."

But in principle and social life of society, Islam recognizes the entities of other religions and allows its adherents to perform and carry out their respective worship. Islam never forces a person to convert to Islam. Because one's faith can be accepted if it is done voluntarily without any force. There is no point in the faith of someone born of coercion. For what Islam is forced, even though the truth and instructions are very clear to anyone who wants the truth of Islam. ${ }^{8}$

An inclusive attitude exists because Al-Qur'an teaches the understanding of religious plurality. For Muslims, it is believed that there is a diversity of religions in this world till now. Although there are claims that the truth of religion exists in Islam, as stated in Q.S Ali Imran: 13,

Meaning: "Indeed there was a sign for you in the two hosts (which) met" together in encounter; one party fighting in the way of Allah and the other unbelieving, whom they saw twice as many as themselves with the sight of the eye and Allah strengthens with His aid whom He pleases; most surely there is a lesson in this for those who have sight."

However, Al- Qur'an also mentions the right of others to religion and religion can not be forced on others as stated in the Q. Al-Baqarah: 256

Meaning: "There shall be no compulsion in [acceptance of] the religion. The right course has become clear from the wrong. So whoever disbelieves in Thaghut ${ }^{10}$ and believes in Allah has grasped the most trustworthy handhold with no break in it. And Allah is Hearing and Knowing."

This attitude becomes the principle during the heyday of Islam and also underlies the political policy of religious freedom. ${ }^{11}$ Islamic inclusivism also provides a formulation that Islam is an opened religion. Islam rejects exclusivism, absolutism, and gives a high appreciation to pluralism. This needs to be instilled to students in Islamic education in order to creat an inclusive attitude as well as positive tolerance among

\footnotetext{
${ }^{8}$ Sayyid Thanthawi, Al-Tafsiral-Wasith, jilid1,(Maktabah Syamilah,t.t), p. 473

9 The meeting between the two groups-between the Muslims and the Polytheists-happens in the Badar War. Badar is the name of a place located between Mecca and Madinah where there is a water spring.

${ }^{10}$ Thaghut is a devil and whatever is worshiped except from Allah SWT

11 Yaya Suryana dan Rusdiana, Pendidikan Multikultural Suatu Upaya Penguatan Jati Diri Bangsa,(Bandung: CV. Pustaka Setia, 2015), p. 329.
} 
religious communities. In line with the spirit of Al-Qur'an so that the phenomenon of lahiriyah does not preclude efforts to reach the meeting point (kalimatunsawa) between all of them as stated in Q.S Ali Imran: $64^{12}$

Meaning: "Say, O People of the Scripture, come to a word that is equitable between us and you - that we will not worship except Allah and not associate anything with Him and not take one another as lords instead of Allah." But if they turn away, then say, "Bear witness that we are Muslims [submitting to Him]."

Even if the linguistic and verbal formulations of religious beliefs differ, it can be ensured that the externalization of the faith in the human dimension must be the same. The monotheism doctrine in Islam implies the existence of a single order as well as comprehensive. In other words there is a universal eternal law.

In the level of theology, inclusive is the opposite of exclusive. The problem of inclusion and exclusion in Islam is a continuation of neomodernism ideas in a more specific area after pluralism, precisely in the field of theology. 13 Religion should be able to be a booster for humanity to always uphold peace and improve the welfare of all humanity on this earth. Unfortunately, in real life, religion is often be one of the causes of humanity's violence and destruction. The bitter truth that concerns to the life of a religious community is experienced by a variety of religious adherents and occurs throughout the world.

Thus all humans are brothers because they are God's creatures. The existence of equality of beliefs between God's creatures and a sense of brotherhood as according to Harun Nasutian in Yaya Suryana, can be the basic of tolerance ${ }^{14 .}$ The existence of that belief assumes that His creation is also essentially a unity. This opinion leads to the conclusion that the entire universe includes all human beings, whatever the nation and languages are God's creatures, even though their religion and beliefs are different ${ }^{15}$.

Empirical evidence of the history of Islamic civilization in the past that indicates Islam appeared inclusively and highly valued non-Muslims. ${ }^{16}$ This inclusive attitude exists because Al-Qur'an teaches plurality religious understanding. ${ }^{17}$ For

${ }^{12}$ Ibid.

${ }_{13}$ Nurcholish Madjid. Islam Kemodernan dan Keindonesiaan, (Jakarta: Mizan, 1987), p.70.

14 See Yaya Suryana dan Rusdiana, Pendidikan Multikultural ..., p. 330.

15 Ibid.

16 Nurcholish Madjid, Islam Doktrin dan Peradaban, (Jakarta: Yayasan Paramadina,1992), p.102.

17 The doctrines of religious pluralism emphasize the understanding that all religions are 
Muslims, a belief professed that even today in this world there will be a diversity of religions. Although there are claims that the truth of religion is in Islam, ${ }^{18}$ the Qur'an also mentions the right of others to have religion. And religion cannot be forced on others. ${ }^{19}$ This attitude become the principle during the heyday of Islam and also underlies the political policy of religious freedom.

b) Exclusive (al-inghilaq), People who have an exclusive attitude will always admit the truth of their religion, even only theirs that are true. This opinion cannot be said to be wrong, because of the intrinsic encouragement of their religion that underlies such this opinion. The truth of the religion that is believed by its adherents is a must because it will awaken the spirit to build a commitment to his religion. If the opinion is followed by religious tendencies which tend to be extreme, by making the others as an enemy that must be shunned, this exclusivity has entered the realm of "extreme exclusivity". Which of course will be a very bad effect in the social order of life will even obscure the meaning of religion itself. Because religion is only used as a cover to create mischief and damage on earth.

It would be even more dangerous if that extreme attitude is applied to aspects of Islamic doctrines concerning social relations between human beings, for example about amar ma'ruf nahi munkar, the duty of jihad, and so on. Such an implementation has lately often led to the connotation of Islam as a violent and fierce religion. However, this image is not in accordance with the nature of Islam which is gentle and compassionate (rahmatan lil'alamiin). With this iqtishaad attitude, then a Muslim can avoid behavior that burdens / complicates oneself or interferes (moreover) harming others $^{20}$.

The reality on the outside shows that there is still religious education taught exclusively by denying the right to life of other religions, as if only the religion itself is right and has the right to life, while other religions are wrong, lost and threatened with

given the freedom to live, with the risk will be born by the adherents of each religion, both individually and in groups. This attitude can be interpreted as a hope for all religions that exist: that is because at first, all religions adhere to the same principle, namely the human obligation to surrender to the Almighty, so the religions, either because of their own internal dynamics or because of contact with each other, will gradually find the truth in all, so that the religions, either because of their own internal dynamics or because of the contact of values one another, will gradually find their own truth, so that all religions rest on one meeting point or in thermonologial-the Qur'an is called kalimah sawa

${ }^{18} \mathrm{QS}$. ÂliImrân:13.

${ }^{19}$ QS.al-Baqarah:256.

20 Muhammad Tolhah Hasan. Agama Moderat: Pesantrendan Terorisme, Jakarta: Listarafiska Putra.2004) p. 23. 
the right to live, both among the majority and minority. This spirit of narrow religious education, of course, fundamentally opposes the spirit of multicultural education, and will weaken national unity. Therefore, Islamic religious education must be revitalized and actualized in a creative and multicultural perspective so that it does not lose its soul and enthusiasm.

\section{The Understanding of Multicultural Education}

According to $\mathrm{M}$. Thholchah Hasan in multicultural education as an option for overcoming radicalism, Multiculturalism is basically a concept where a community in the national context can recognize the difference, the difference and diversity of cultures, races, religions, and languages. Multiculturalism is a picture of the diversity that occurs and develops in a society or in a nation on this earth. ${ }^{21}$ Multiculturalism is also a concept that provides understanding, that a pluralistic nation is a nation consisting of various ethnicities, cultures, religions, traditions and languages, which can coexist and respect each other in an atmosphere of peace and harmony (coexistence)

Multicultural education is a process of developing all the potential of students through the application of educational concepts based on the utilization of diversity that exists in the community, especially those that exist in students such as ethnic diversity, culture, language, religion, social status, gender, ability, age, ethnicity and race. ${ }^{22}$

Multicultural education is defined as a social policy based on the principles of cultural preservation and mutual respect between all cultural groups in society. Multicultural learning is basically an educational program for multicultural communities to participate in realizing an ideal democratic life for their nation. ${ }^{23}$

According to Callary Sada that multicultural education has four meanings:

1) Teaching about cultur

2) Teaching about varior

3) Teaching to advance status in society

4) Teaching about diversity reflection to enhance pluralist values in the field of equality values. ${ }^{24}$

21 Muhammad Tolchah Hasan, Pendidikan Multikultural Sebagai Opsi Penanggulangan Radikalisme.(Malang:Lembaga Penerbitan Universitas islam Malang(Unisma), 2016), p. 9.

22 M. Ainul Yaqin, Pendidikan Multikultural: Cross-Cultural Understanding untuk. Demokrasi dan Keadilan. (Yogyakarta:Pilar Media, 2005), p. 5.

23 Thobroni, Muhammad dan Mustafa, Arif, Belajar dan Pembelajaran: Pengembangan Wacanadan Praktik Pembelajaran dalam Pembangunan Nasional. (Yogyakarta: Ar-Ruzz Media, 2011), p 396.

${ }^{24}$ Clarry Sada, Multivultural Educationin Kalimantan Barat, an Overview, (Jurnal Multicultural Education in Indonesia and South East Asia Edisi pertama, 2004) p. 85. 
Multicultural education is an important value in education that must be fought for. Because it is needed as a foundation for the establishment of a democracy in an area, human rights and the welfare of people's lives.

Indonesia is one of the largest multicultural countries in the world. In addition, Indonesia is also a multi-religious, because its population adheres to a variety of religions, namely Islam, Catholicism, Protestant Christianity, Hinduism, Buddhism, Confucianism, as well as various kinds of religious beliefs. The diversity of the Indonesian nation is not only as a treasure of national cultural wealth and the nation's strength but also cause various problems or conflicts. Corruption, collusion, nepotism, political conflicts, separatism, riots between countries and religions, are forms of multiculturalism, multiculturalism phenomena. ${ }^{25}$

Whereas it is related to the content of multicultural values in Islam, Prof. Assegaf is more complete and detailed in dividing into three categories. First, the main values which include: Tauhid (acknowledge the oneness of God), Ummah (living together), rahmah (affection), al-musawah, taqwa (egalitarianism). Second, the values of application: Ta'aruf, Ihsan (know each other and do the good), tafahum (understand each other), takrim (respect each other), fastabiqul khayrat (competing in kindness), trustful (trust each other), husnuzhan (positive thinking), tasamuh (tolerance), 'afw, magfirah (giving / asking for forgiveness), sulh (peace), islah (conflict resolution). Third: the values of goals: silah, salam (peace), layyin (gentle or non-violent culture), and 'adl (justice). ${ }^{26}$

Multicultural education indicates the diversity. Multicultural education also emphasizes a philosophy of cultural pluralism into the education system based on the principles of equality, mutual respect and acceptance as well as understanding and a moral commitment to social justice which can later be used as the main value to be able to answer various horizontal conflicts and vertical in the world of education in the era of globalization. In the application of multicultural education, this educational strategy not only aims to make it easy for students to understand the lessons learned in the classroom, but also to increase student awareness in order to always behave humanist, pluralist, and democratic which are the main values in social activities.

\section{Inclusivism And Exclusivism And Its Effects On Multicultural Education}

In general, Islamic religious education provided in schools has not fully revived good multicultural education, and even tends to be the opposite. As a result, social

\footnotetext{
25 Abd. Rahman Assegaf, Filsafat Pendidikan Islam, (Jakarta: Rajawali Press, 2011), p. 205.

${ }^{26}$ Ibid..., p.313-314.
} 
conflicts are often hardened by religious legitimacy taught in Islamic religious education in conflict-prone regional schools. This makes the conflict has roots in fundamental religious beliefs so that social conflicts and violence are increasingly difficult to overcome, because they are understood as part of their religious vocation. ${ }^{27}$

The reality on the real condition shows that there is still religious education taught exclusively by denying the right to life of other religions, as if only the religion itself is right and has the right to life, while other religions are wrong, lost and threatened with the right to live, either among the majority and the minority. This narrow spirit of religious education, of course, fundamentally opposes the spirit of multicultural education, and will weaken national unity. Therefore, Islamic religious education must be revitalized and actualized in a creative and multicultural perspective so that it does not lose its soul and enthusiasm.

According to Din Syamsuddin, why religion has such ambivalence, one of them is that religion has an absolutistic tendency, namely the tendency to make its religious beliefs as a single truth. The result was a rejectionist, namely rejection of the truths of other religions that were considered different from and opposing the others. 28 The roots of religious conflicts such as this said Arthur D'Adamo because the adherents of the religion take the attitude to look at religion from the point of view of their own religion. ${ }^{29}$ So that what surfaces more is not the essence of truth that religion wants to offer, but the spirit to negate others.

Because of that truth claim, every religion declares its doctrines to be a totality of meaningful systems that apply to all life, both individually and socially so that it naturally tends to affirm its theological truth claims. But when these religions exist historically, they are confronted with religious pluralism as a social reality that lives in the midst of society, which will have implications for social behavior. It is in this context that an inclusive view is essential to accept the reality of pluralism ${ }^{30}$ as an absolute requirement for adherents of any religion.

${ }^{27}$ Choirul Mahfud, Pendidikan Multikultural,(Yogyakarta:Pustaka Pelajar, 2013), p. 96.

${ }^{28}$ M. Din Syamsuddin,"Mengelola Pluralitas Agama" dalam Jawa Pos, (12 Mei 1996), p.4-5.

${ }_{29}$ Budhy Munawar Rachman, "pengantar" dalam Komaruddin Hidayat dan Muhammad Wahyuni Nafis, Agama Masa Depan Perspektif Filsafat Perennial, (Jakarta: Yayasan Paramadina,1995), p.xxiv-xxvii

${ }^{30}$ There is an understanding of plurality which is not necessarily accompanied by pluralism. The plurality is merely a plurality of reality, whereas pluralism is a concept that accepts the plural reality as something positive. The pluralism also does not merely show the reality of the existence of diversity but what is meant is an active involvement in the reality of the diversity. See Nurcholish Madjid,"Hak Asasi Manusia, Pluralisme Agama, dan Integrasi Nasional(konsepsidanaktualisasi)" dalam HAM dan Pluralisme Agama,(Surabaya:PKSK,1997), p.71. 
Multicultural education is a social policy based on the principles of cultural preservation and mutual respect between all cultural groups in society. Multicultural education is basically a nation's education program so that multicultural communities can participate in realizing an ideal democratic life for the nation. This makes a country has its own identity and values in facing various kinds of challenges in an increasingly complex global era, especially in the field of education in Indonesia.

As, it is known that educational practices and processes, especially that take place in educational institutions, have a role in shaping the character and behavior of each student. Therefore, each learning process, especially religious education (Islam) should consider the need to insert civic values in learning activities so as to be able to print outputs that have multicultural awareness and apply them in everyday life.

\section{CONCLUSION}

Multicultural-based religious education is a process of awareness based on tolerance aimed at comprehensive efforts in preventing inter-religious conflict, preventing religious radicalism, while at the same time fostering the realization of positive appreciative attitudes towards plurality, inclusivism in any dimension and perspective rather than promoting exclusivism. Religion should be able to be an incentive for humanity to always uphold peace and improve the welfare of all humanity on this earth. Unfortunately, in real life, religion is often one of the causes of human violence and destruction. Thus, the fulcrum of multicultural inclusivism based religious education actually lies in the understanding and effort of mujahadah to live together in the context of religious and cultural differences. 


\section{REFERENCES}

Assegaf, Abd. Rahman, Filsafat Pendidikan Islam, (Jakarta: Rajawali Press, 2011)

Hasan Muhammad Tolhah, Agama Moderat: Pesantrendan Terorisme, Jakarta: Listarafiska Putra.2004)

-----------, Pendidikan Multikultural Sebagai Opsi Penanggulangan Radikalisme, (Malang Lembaga Penerbitan Universitas islam Malang (Unisma), 2016)

Hasan, Moh Abdul Kholiq, Merajut Kerukunan Dalam Keragaman Agama Di Indonesia (Perspektif Nilai Nilai Al-Quran) PROFETIKA, Jurnal Studi Islam,Vol.14,No.1,Juni 2013

Lutdjito, Ahmad, Filsafat Nilai dalam Islam dalam Chabib Thohaet.al, Reformulasi Filsafat Pendidikan Islam, (Yogyakarta: Pustaka Pelajar dan FT.IAIN Walisongo Semarang, 1996)

Madjid, Nurcholish, HAM dan Pluralisme Agama, (Surabaya: PKSK, 1997) Islam Doktrin dan Peradaban, (Jakarta: Yayasan Paramadina, 1992) Islam Kemodernan dan Keindonesiaan, (Jakarta: Mizan, 1987)

Mahfud, Choirul, Pendidikan Multikultural,(Yogyakarta:Pustaka Pelajar, 2013)

Moleong, Lexy J, Metodologi Penelitian Kualitatif (Bandung: Remaja Rosda karya, 2006)

Rachman, Budhy Munawar "pengantar" dalam Komaruddin Hidayat dan Muhammad Wahyuni Nafis, Agama Masa Depan Perspektif Filsafat Perennial, (Jakarta: Yayasan Paramadina, 1995)

Sada, Clarry, Multivultural Educationin Kalimantan Barat, an Overview, (Jurnal Multicultural Education in Indonesia and South East Asia Edisi pertama,2004) Suryana, Yaya, dan Rusdiana, Pendidikan Multikultural Suatu Upaya Penguatan Jati Diri Bangsa,(Bandung: CV. Pustaka Setia, 2015)

Syamsuddin, " M. Din, Mengelola Pluralitas Agama" dalam Jawa Pos, (12 Mei 1996)

Thanthawi, Sayyid, Al-Tafsiral-Wasith, jilid1,(Maktabah Syamilah,t.t)

Thobroni, Muhammad dan Mustafa Arif, Belajar dan Pembelajaran. Pengembangan Wacanadan Praktik Pembelajaran dalam Pembangunan Nasional. (Yogyakarta: Ar-Ruzz Media, 2011)

Yaqin, M. Ainul, Pendidikan Multikultural, Cross-Cultural Understanding Untuk Demokrasi dan Keadilan, (Yogyakarta: Pilar Media, 2005)

Zukarnain, Iskandar "Realitas Keagamaan di Indonesia dan Inklusifitas Islam", makalah seminar, di LorInSolo,18-20 Juni2012. 